\title{
SOBRE A TÉCNICA
}

\author{
ON TECHNOLOGY
}

Ricardo Lafetá Novaes*

NOVAES, R. L. 'About Technique'. História, Ciência Saúde - Manguinhos, III (1): 24-49 Mar-Jun. 1996.

Based on conceptions forged in classic Greece, the article affirms the idea of technology as a "way of doing" that is underpinned by forms of organization produced by the society where the technology has emerged and by the knowledge produced in each era. Emphasizing aspects of specific moments in Western history, it goes on to identify relations between technology and science - understood bere as the search for maximum rationality. The article questions certain positions which would seem to contend that techno-science contributes to the production of social inequalities and injustice, given a kind of collusion between knowledge and power. In the case of medicine, it is held that modern science has paved the way for ever more efficacions technology for intervention that benefits humankind; furthermore, the failure to solve all of humanity's problems derives much more from the political character of these inequalities than from any specific role that science and technology could play in achieving such a solution.

KEYWORDS: technique, science, social inequalities, medicine.

\section{Concepções}

* Professor doutor do Departamento de Medicina Preventiva da Faculdade de Medicina da Universidade de São Paulo(USP).

Av. Dr. Arnaldo, $455-$ $2^{\mathrm{Q}}$ andar

São Paulo - SP

01246-103
Aristóteles, depois de ter sido, por dois anos, preceptor de Alexandre, retorna a Atenas para ali fundar uma escola claramente diferente daquela criada por seu mestre Platão. Contra o mito da caverna, formula a hipótese de uma vida "subterrânea", onde, ao invés da escravidão, os trogloditas encontram uma harmonia característica de um doce lar "ornado de esculturas e pinturas" repousantes. Não se põe, para estes tranqüilos habitantes, o penoso esforço de uma "dialética ascendente" em busca da luz emanada do Bem, como queria Platão. Ao contrário, somente se a luz do sol se lhes apresenta, movem-se em direção a ela motivados por uma nova beleza, plenamente perceptível pelos sentidos que os tornam homens.

O mundo é o que é e a sua ORDEM é o dado primeiro a ser apreendido e compreendido a partir da vivência que nele se tem. Não sendo réplica de um "mundo das idéias", o seu entendimento se faz pela via do alargamento da experiência, que encontra na ciência a forma de identificar as articulações que lhe dão sentido.

O mundo, pensa Aristóteles, é não mais que movimento posto em marcha por um "motor primeiro", imóvel, que engendra tudo que é sentido e/ou percebido. Causa primeira, o Demiurgo conforma a matéria visando as finalidades. Em outros termos, a 
plena existência do Ser se concretiza na FORMA que the dá sentido, florescendo em "valor de uso", causa final. A natureza (physis) aristotélica, concebida como "autodesenvolvimento", comporta diferenciações relativas aos processos experimentados:

"com efeito, entre aqueles que são, uns são por natureza e outros por outras causas. Por natureza são os animais e suas partes, as plantas e os corpos simples como a terra, o fogo, o ar e a água porque são coisas tais e de tal sorte que dizemos ser naturais. Ora, todos os que são que acabamos de anunciar parecem se distinguir das coisas que não são constituídas pela natureza porque, cada um entre eles, possui, em si mesmo, um princípio de movimento e de estabilidade, uns segundo o lugar, outros segundo o crescimento $\mathrm{e}$ a diminuição, outros ainda segundo a alteração. Por outro lado, um leito, uma vestimenta e, a supor que ele existe, qualquer outro gênero desta espécie que se encontra em cada uma destas categorias e que, portanto, são produzidos por uma ARTE não possuem neles nenhum elã inato que os impulsiona a mudanças ainda que, de outra parte, por serem feitos de pedra ou de terra (até mesmo da mistura dos dois) eles possuem tal elã tão-somente na medida em que a natureza é princípio e causa de movimento e repouso e naquilo que thes é inerente e não por acidente. Digo bem, não por acidente, porque poderia ser que, sendo médico, qualquer um seja a causa de sua própria saúde; todavia, não é pelo fato de estar em vias de se curar que alguém possui a arte médica, embora aconteça que um seja médico e se cure a si próprio; é por isso que estas atividades podem ser separadas" (Aristóteles, 1991).

Claramente distintas, mas inseparáveis, natureza e arte se complementam tendo em vista a "causa final", o produto desejado. Techné, é o termo grego para designar uma "ordem de produção" que pressupõe um engendramento, uma criação de modos de fazer, engenho e arte. É esta exterioridade relativamente aos movimentos naturais da physis que qualifica o intelecto não como mero imitador da natureza, mas como criador que pode até "superá-la", produzindo o que ela, por si só, não logra engendrar. Donde uma primeira "definição": técnica é um modo de fazer, novo em relação ao "fazer natural", assentado e envelhecido no e pelo próprio ato de sua instauração. Nessa concepção, pode-se identificar uma "dupla novidade": a natureza, que tem por essência o florescimento, é sempre novidade em relação à sua causa final, posto que sempre geradora; tendo gerado o intelecto humano, aloca em sua essência a faculdade da arte, de criação daquilo que ela própria não engendra, não importando os motivos pelos quais não o faz.

Nesta explicação do "movimento do mundo", um status positivo pode ser atribuído à arte: atividade pela qual finaliclades úteis são alcançadas, superando aquilo que naturalmente é posto para 
usufruto. Em outros termos, o 'florescimento' da physis, por si só, não resulta suficiente para o atendimento das necessidades postas e criadas pela alma humana. Mas que necessidades são estas, passíveis de serem atendidas por modos de fazer específicos, pelo engenho e pela arte? Não se pode, em primeiro lugar, deixar de lembrar o belo, esculpido na dureza fria e bruta do mármore, matéria indeterminada que, pela forma adquirida, exprime o calor sutil de um êxtase maior, testemunho de uma harmonia desejada. Não por acaso, Aristóteles se vale do exemplo do leito para clarificar o movimento que faz florescer a causa suficiente que, pela matéria configurada em forma, cumpre precípuas finalidades no mundo organizado. $\mathrm{O}$ mesmo serve para as habitações, sistemas hidráulicos e... engenhos de guerra.

Ocorre que tal 'fazer as coisas' demandava a utilização do instrumento primeiro, a pinça natural que caracteriza os primatas, revestida de sentido maior quando se trata daquele capaz de antever a finalidade da coisa. A técnica é, essencialmente, trabalho humano manual, pois é dele que deriva a forma, ainda que intelectualmente maquinada.

Aristóteles, como se sabe, dividia a filosofia em três classes de ciências: as ciências teóricas, que têm por objeto o saber ou a verdade - as matemáticas, a física e a teologia; as ciências práticas, que estudam as ações em si mesmas; e as ciências poéticas, que estudam a produção de uma obra exterior ao agente. Divisão não fortuita e não elaborada para, simplesmente, recobrir especificidades de objetos. Na verdade, uma divisão ordenada que encobre uma clara definição de hierarquia posto que a teoria é, em tudo, superior a qualquer prática. Principalmente no contexto da democracia grega, sociedade desigual na qual o escravo foi pensado como 'máquina animada' para justificar, teoricamente, a inferioridade do trabalho manual, da força muscular produtora de bens necessários ao exercício da liberdade, do prazer do belo e da paz prometida pela sonhada harmonia do cosmo. A técnica, assim, positivada pela reflexão, é remetida ao seu devido e inferior lugar, negativamente valorada por uma sublime ascese.

Valor negativo elaborado no berço da civilização ocidental e que se prolonga por séculos, às vezes nuançado, mas sempre cultivado. Assim foi com o Império Romano, tornado possível através de uma expansão jamais vista do "modo de produção escravagista". É certo que, considerado um período histórico paupérrimo em termos de filosofia e ciência, muitos aperfeiçoamentos técnicos ali se registraram: utilização de argamassa preparada pela mistura de óxido de cálcio, areia e água, na construção de edifícios; aquedutos e sifões invertidos (em chumbo) onde os primeiros eram de difícil construção; vias carroçáveis em extensão e qualidade até então não vistas; aperfeiçoamento . 
da metalurgia (foles de couro) e da navegação. Tudo assentado, basicamente, na força muscular, animal ou humana.

A Idade Média, com alguma razão, é tida como o "período das trevas". Mundo da verdade revelada, espaço de captura e posse dos espólios do grande Império, terras de invasões ditas bárbaras, o Ocidente se fecha sobre si mesmo, buscando consolidar uma nova supremacia, garantida por uma divindade única que rapidamente espalhou seu manto sobre a civilização. O cristianismo vem a ser a nova regra de organização social sustentada, bem se sabe, pela convicção de espadas, estas sim, em franco 'desenvolvimento tecnológico'. O servo o era por desígnio, primeiro divino e, por via das dúvidas, pela força do seu próprio e próximo senhor. A coerção era, fundamentalmente, extra-econômica, já apontou Marx (1973). Se o escravo (máquina animada ou simples (coisa') era produto de uma derrota militar, o servo o é por uma diferença estabelecida pela própria natureza, tal como desenhada pelo Criador. O trabalho manual, mais do que inferior, vem a ser degradante, pois indica, com precisão, a posição de cada segmento humano na sociedade: uns (a imensa maioria) atrelados à terra, outros poucos, próximos do céu. Degradante porque também pesado, este trabalho.

Do que se trata, afinal? Do cultivo da terra, de extrair o que nela é natural e da sua manufatura, do transporte. Tudo, quase que exclusivamente, à base da força muscular. Esforço que, certamente, estimula o trabalho mental que visa reduzi-lo, ainda que na ausência de uma referência 'científico-racional'. Os modos de fazer (técnicas) não são sempre, necessária e mecanicamente, derivados dos "modos de conhecer" (ciência), diria Canguilhem. Assim, em um contexto de uma "verdade" revelada, algumas inovações nos "modos de fazer" (tecnologia) foram aflorando, como aponta, por exemplo, Jacomy (1990).

Uma primeira e notável se verifica na agricultura, a partir do século $X$. Mudanças no arado, que passa não só a fazer sulcos mais profundos, como também a cortar horizontalmente a terra $e$ as raízes não desejadas ali encravadas e, adicionalmente, revolvendo o solo assim trabalhado. Em conexão com as invasões bárbaras (e sua 'cavalaria ligeira'), a tração animal potencializa a 'força de trabalho', até então penosa e de baixo rendimento. Finalmente, em relação ao cultivo da terra, introduz-se a rotação trienal, segundo a qual um terço da área permanece em repouso, um terço é usado para plantio de inverno e o restante, para plantio de verão. Um aumento da produtividade que, paulatinamente, vai modificando a forma de organização espacial da sociedade feudal: ao lado das velhas cidades, núcleos de populações rurais concentram atividades manufatureiras (principalmente têxteis) e comerciais. 
De outra parte, e a partir do século XII, as cidades que conquistam o status de sede episcopal assistem a uma verdadeira febre de louvor a Deus, com a edificação de templos que buscam, cada vez mais, uma aproximação com o Senhor. Principalmente no norte da França, as catedrais começam a recortar os céus com altos perfis até então inimaginados, à custa de uma inovação construtiva: os arcobotantes. Enormes canteiros, proporcionais às dimensões das obras, testemunham aperfeiçoamentos na elevação e assentamento de grandes blocos de pedra, no seu entalhamento e transporte, no trabalho de pedreiros, carpinteiros, marceneiros, fundição e forja, vidraria etc. Assim, apesar da ordem política e jurídico-ideológica, os séculos XIII e XIV vivenciam uma pequena efervescência artesano-comercial que impõe a expansão e o aprimoramento de vias navegáveis (até mesmo com a abertura de canais), incluindo elementos inovadores, como as eclusas, por exemplo. Às vésperas do Renascimento, dá-se a introdução de uma novidade que hoje pode até nos parecer quase risível, mas de enorme utilidade para a época, que foi o carro a quatro rodas e, ainda, o relógio mecânico à mola, cuja função não pode ser comparada à de nossos dias, dada a diferente dimensão temporal. Para o conjunto do período, não se pode esquecer a adoção generalizada do moinho à água, força motriz poupadora de energia humana e animal. Por isso, aos olhos de Jacomy (1990, p. 167), entre os de outros e conhecidos autores, as trevas da Idade Média não são tão profundas:

"Longe de aparecer como um período sombrio de nossa história, percebe-se, à luz das numerosas inovações que apontei, que a Idade Média reveste, no domínio da técnica, uma importância de primeiro plano. O período que vai do $12^{\circ}$ ao $16^{\circ}$ séculos, longe de marcar o passo, comporta o germe dos principais elementos sobre os quais se construirá a grande revolução industrial do fim do século XVIII. Nasce uma nova cultura técnica que não está muito afastada de nossa cultura contemporânea."

Visão otimista, talvez, mas que aponta uma positividade da arte, mesmo quando um valor negativo a ela é atribuído. De outra parte, em um mundo dominado por um "saber" revelado, a questão de um eventual suporte positivo como a ciência (tal como hoje considerada) nem sequer se colocava. Desqualificado, o trabalho manual (suporte da arte) só adquire valor positivo quando um novo modo de produção se inaugura na civilização ocidental após ter este mundo, inclusive, assistido a um período de renovações culturais, literárias e estéticas. 


\section{Mudanças}

O Renascimento foi um época extremamente fecunda em relação a mudanças nas 'visões de mundo' e dos modos de 'estar no mundo'. Tudo se assenta em um progressivo mal-estar. Quando Constantino assina o edito de Milão (313), concedendo não só liberdade religiosa aos cristãos, mas restituindo-lhes seus bens, a ideologia religiosa cristã se vê consagrada cọmo hegemônica no mundo ocidental. Desde ali, mil anos seriam necessários para que seu instrumento, a Igreja Católica, consolidasse seu poder sobre os tempos. O papado, guardião centralizador da verdade revelada, firma-se como avalista da supremacia de uns poucos sobre muitos outros. Sobre a verdade, o pensamento deve ser guiado pelas rígidas regras aristotélicas para, como queria Tomás de Aquino - pai da escolástica -, delimitar o alcance dos conhecimentos humanos, visando preservar o entendimento de Deus como 'primeiro motor'. Quanto ao cotidiano do 'aqui embaixo', nenhuma inovação diante do implemento da força das armas que logram, finalmente, uma quase universal e fervorosa adesão ao partido de Deus e a Seu instrumento.

Regras não exatamente aderentes a um mundo real, que se expandia em muitos sentidos: aumento da população, da produtividade agrícola, de núcleos populacionais que pouco a pouco vão se transformando em burgos, assentados que estavam em um artesanato crescente e, fundamentalmente, em uma florescente atividade comercial. As insatisfações manifestam-se em um crescendo. Lutero reage, não exata e exclusivamente aos princípios, mas ao que lhe parece ser uma excessiva cobiça traduzida pela venda de indulgências, objetivando a construção de um templo que, por sua imensidão, refletisse a grandiosidade do Criador. Por uma outra vertente, o comércio permite a príncipes italianos inventar o mecenato, condição propícia a vôos mais altos da imaginação. Quando Maquiavel (1973, p. 9) envia ao magnífico Lorenzo aquilo que lhe parece o mais precioso, pois que, "considerando que não lhe posso fazer maior presente que lhe dar a faculdade de poder em tempo muito breve aprender tudo aquilo que, em tantos anos e à custa de tantos incômodos e perigos, hei conhecido", a questão colocada era evidente: como, sem depender de forças externas, governar e conservar os principados? O Príncipe é uma resposta clara: as coisas da terra devem, pelos homens, ser dirigidas, de maneira "objetiva", sem considerações outras que aquelas do político.

O humanismo é a reação ao pensamento que atava a criatura aos absolutos desígnios do Criador. Novo "centro", ao homem cabe liberar-se do rígido discurso da verdade eternamente revelada. Pois, diz Koyré (1973, p. 54), o ideal de civilização do 
Renascimento é ainda o da retórica, e não o da ciência. O seu "tipo característico" é o do grande artista, mas, sobretudo, o do homem de letras. O humanismo é, fundamentalmente, uma reação contra a escolástica e, por desdobramento, contra o aristotelismo e o "paradoxo" que ele encerra. Compreende-se bem. Se por um lado, a natureza aristotélica (physis) é um permanente desabrochar, um florescimento contínuo que se dá no 'corrupto' mundo sublunar, por outro, tudo que está acima da esfera da lua, é regido por leis fixas e imutáveis que lhe garantem a perfeita harmonia. O cosmo é fixo, inclusive a Terra no seu centro:

"Na física e na cosmologia aristotélicas, para traduzi-las em uma linguagem mais moderna, é a estrutura mesma do espaço físico que determina o lugar dos objetos que nele se encontram. A Terra encontra-se no centro do mundo pois, pela sua própria natureza, ou seja, porque ela é pesada, ela deve se situar no centro. Os corpos pesados se dirigem a este centro, não porque algo lá se encontra ou porque alguma força física os atrai; eles se dirigem ao centro porque sua natureza os impele."

Dupla negação, poder-se-ia dizer. Deus criador não é o centro do agir, mas sim o homem, ainda que por Ele o faça; a Terra não é o centro, mas sim o Sol. Inclusive porque, brilhante, o astro-rei expressa melhor a dignidade divina. Interpretação religiosa, sem dúvida, mas também assentada em arrazoados e procedimentos inovadores. Sigamos Koyré (idem, p. 55):

"Se os corpos pesados, diz-nos Copérnico, dirigem-se para a terra, não é porque eles se dirigem ao centro, ou seja, para um determinado lugar do Universo; eles para lá vão, simplesmente porque querem retornar à terra. O raciocínio copernicano faz aparecer uma realidade ou um vinculo físico substituindo uma realidade e um vínculo metafísico; substituição de uma estrutura cósmica por uma força física. Assim, qualquer que seja a imperfeição da astronomia copernicana do ponto de vista físico ou mecânico, ela, no entanto, identificou a estrutura física da terra àquela dos astros celestes dando-lhes, a todas, um mesmo movimento circular. Por aí, esta astronomia assimilou, um a outro, os mundo sublunar e supralunar, realizando a primeira etapa de identificação da matéria ou dos seres que compõem o Universo, a primeira etapa da destruição de uma estrutura que dominava o mundo aristotélico."

O segundo passo em direção à unificação do mundo foi dado por Tycho Brahé, pela precisão de suas observações, dos fatos, das medidas e na fabricação dos instrumentos necessários à observação e à medida. Aí se encontra a base do trabalho de- 
senvolvido por Kepler, que parte do reconhecimento de que Tycho Brahé foi o demolidor da concepção das esferas celestes, suporte dos planetas que envolviam a Terra e o próprio Sol:

"O que é radicalmente novo na concepção de Kepler é a idéia de que o Universo é, em todas as suas partes, regido pelas mesmas leis, e por leis estritamente matemáticas. Seu Universo é, sem dúvida, um Universo estruturado, hierarquicamente estruturado em relação ao Sol, harmoniosamente ordenado pelo Criador ... que, ao fazê-lo, é guiado por considerações estritamente matemáticas ou geométricas" (ibidem, p. 56).

É ele quem promove a passagem de uma concepção animista do Universo para aquela mecânica, visto que não vale a pena recorrer a 'almas' para explicar o movimento dos corpos, se forças materiais ou semimateriais (luz e magnetismo) são explicações suficientes. O mecanismo é suficiente justamente porque os movimentos planetários seguem leis estritamente matemáticas, diz Koyré. Apenas o movimento pois, como bom aristotélico, Kepler não vê necessidade de explicar o repouso: uma força motora produz somente a velocidade e não a aceleração.

Pensar a existência de leis únicas, matemáticas, para a totalidade do Universo não significa uma ruptura radical. Ainda nos marcos aristotélicos, Kepler transita pela finitude do cosmo: para além da última das esferas que suportam todos os corpos celestes há o nada, ou melhor, não há nada, não há o pensável. Como afirma Koyré (ibid., p. 58):

"Ele está sempre dominado por uma determinada idéia do mundo, expressão do Criador e mesmo da divina Trindade. Assim, ele vê no Sol a expressão de Deus Pai; no mundo estrelar, a de Deus Filho, e na luz e na força que circulam entre os dois, no espaço, a expressão do Espírito Santo. É justamente esta fidelidade a uma concepção de mundo limitado e finito que não permitiu a Kepler romper os liames da concepção aristotélica."

É Giordano Bruno quem, compreendendo a profundidade da reforma da astronomia operada por Copérnico, proclama, ousadamente, a idéia de um Universo Infinito, premissa indispensável para a revolução científica do século XVII e a fundação da ciência clássica, pensa Koyré.

Galileu é o promotor da grande ruptura que encerra, definitivamente, o humanismo letrado do período dito renascentista. $\mathrm{O}$ que o anima é pensar a regularidade das coisas, da redução do real ao geométrico, da identificação da física à geometria euclidiana. Por aí, ele ultrapassa Kepler:

"O Universo galileano, certamente, não é limitado pela abóbada celeste. Também, admite ele que o movimento é uma entidade 
ou um estado tão estável e duradouro quanto o estado de repouso; ele admite, assim, que não há necessidade de uma força constante agindo sobre o móvel para explicar o seu movimento; ele admite a relatividade do movimento e, portanto, a possibilidade de aplicar à mecânica, as leis estritas da geometria" (ibid., p. 58).

Matematizado e tornado infinito, o mundo em movimento (regido pela lei da inércia) não mais necessita de um 'centro' e muito menos de um 'motor primeiro' em constante funcionamento. O escândalo, em outros termos, é a dispensa de Deus e a negação do privilégio por Ele concedido aos homens ao tornar a Terra o centro do universo.

Em que pese a criação de novos instrumentos, tais como o telescópio (teoria ótica materializada, construído para uma específica finalidade científica), representar um primeiro e mais próximo vínculo entre ciência e técnica, o período renascentista não foi tecnologicamente prodigioso. É certo que algumas inovações tiveram papel marcante nas futuras transformações pelas quais passariam o mundo. A navegação, misto de saberes e de coragem, impulsionada pela ampliação de novos interesses comerciais, sem dúvida abriu, também para o pensamento, novos e ilimitados horizontes. Gutenberg proporcionará uma virada sem precedentes no plano cultural, tornando possível uma circulação de idéias antes confinada aos exegetas de manuscritos (como bem nos mostra O nome da rosa, por exemplo). Não é fortuito pois que o humanismo, que experimenta seu apogeu no século $\mathrm{XV}$, tenha, também, como uma de suas características, a enorme curiosidade do homem sobre as coisas do mundo, presentes e passadas. O gosto "pelas letras" reveste-se de uma necessidade de busca das raízes. A língua grega passa a ser aprendida e utilizada como instrumento de acesso ao pensamento e cultura dos tempos clássicos da Grécia Antiga. Saberes e valores, estética e ética antigos, apreendidos, configuram sentimentos de que, por este caminho, a civilização ocidental européia pode 'renascer'.

\section{Trabalho e potência}

$\mathrm{Na}$ verdade, o que se assiste são os primórdios de uma revolução, propriamente social. Agricultura, uma nova urbanização, tecnologia têxtil e, principalmente, um florescente comércio (com seu ramo financeiro), abrindo fronteiras, propiciam a acumulação de novas riquezas, premissa indispensável para mudanças na base técnica da produção material e no modo de produzi-la.

"A ordem econômica capitalista saiu das entranhas da ordem feudal. A dissolução de uma forneceu elementos para a cons- 
tituição da outra. Quanto ao trabalhador, o produtor imediato, para poder dispor de sua própria pessoa, primeiro teve de deixar de estar unido à terra e não ser mais um escravo ou servo de um outro. Não podia, tampouco, ser um livre vendedor de trabalho que oferecesse sua mercadoria onde quer que encontrasse um trabalho, sem ter antes se libertado das corporações, com suas regras para aprendizes e oficiais, suas ordenanças e estatutos. O movimento histórico que converteu os produtores em assalariados se apresenta, assim, como sua libertação da servidão e da hierarquia industrial. Por outro lado, estes libertados se convertem em vendedores de si mesmos somente depois de terem sidos despojados de todos os seus meios de produção e de todas as garantias de existência que oferecia a antiga ordem das coisas" (Marx, 1973, p. 691).

Livre de tudo, a força de trabalho vai adquirindo uma nova 'qualidade': de um trabalho manual, útil, produtor de valor de uso. Considerado 'degradante', passa a uma 'positividade', dado que, agora, encontra-se na base da produção de valor, mais precisamente, de sobrevalor.

Ora, o caráter positivo do trabalho resulta não só em uma potencialização (as forças produtivas são maiores que a simples soma das parcelas), mas, e principalmente, em tecnologias que constantemente aumentam a produtividade. A metalurgia do ferro é um exemplo expressivo, pelas mudanças ocorridas ao longo do século XVIII, com enormes repercussões no século seguinte, aquele do 'grande salto'. De simples elemento fundido e forjado (de resistência relativamente baixa), o ferro, pela introdução do carvão mineral (principalmente na Inglaterra) em substituição ao carvão vegetal, adquirirá um novo papel. A experimentação de novas ligas e a laminação permitiram, pela crescente resistência e novas formas, o surgimento de máquinas-ferramentas, estruturas de edificações e um incremento jamais visto em relação aos transportes. Tudo isso, com a concorrência decisiva de novas fontes energéticas e dos instrumentos de sua transmissão.

Como se sabe, a chave de todo trabalho é a transformação de energia potencial em energia cinética. Não é fortuito que, em física, o trabalho seja definido através de uma relação estabelecida entre força e deslocamento. Assim, se a água e o vento revelaramse fontes energéticas superiores à muscular (humana ou animal), ainda que sua constância não fosse absoluta, a utilização de uma nova e controlável matriz energética representa um domínio extraordinário sobre o processo de trabalho. É certo que o homem já tinha, desde muito antes, o controle sobre o fogo para simples transformações diretas das matérias propriamente ditas: cocção e fusão como modos de fazer principais. A novidade vem a ser a 
obtenção de energia mecânica. Carvão, combustão; calor e pressão; pistão e biela, movimento retilíneo transformado em circular. Esquema simples, mas que demandou muita engenhosidade de Thomas Newcomen e, principalmente, de James Watt, para que, em 1776, surgisse a primeira máquina a vapor. Imagina-se bem o alcance desta verdadeira revolução: passagem de energia natural para aquela 'fabricada', vale dizer, controlada. A indústria têxtil, já mecanizada, liberta-se dos cursos d'água; o mesmo ocorre com as siderúrgicas, que então podem se instalar mais próximo às fontes de matérias-primas, minorando as dificuldades de transportes ainda existentes. Dificuldades que, sem muita demora, serão progressivamente diminuídas.

Em 1783, Jouffroy d'Abbans, diz-nos Jacomy (1990, p. 266), faz um primeiro ensaio de navegação com uma máquina de Newcomen na França, que é repetido, em 1787, por Symington na Inglaterra, dessa vez com o engenho de Watt. Mas é só em 1897 que Robert Fulton constrói o primeiro barco a vapor comercial, navegando entre Nova York e Albany, pelo rio Hudson.

"A navegação marítima surge umas duas décadas mais tarde e a propulsão a vapor é utilizada, ainda por muitos anos, paralelamente à propulsão élica. Estes navios ainda guardam uma silhueta bastante tradicional, com exceção da chaminé que denunciava a existência de uma máquina a vapor. As relações entre a Europa e a América se desenvolvem no ritmo destes novos transportes marítimos. A duração da viagem passa de uns trinta dias, em 1835, para uma quinzena com o Great Western, primeiro transatlântico moderno, e depois para uma semana, em torno de 1860."

A implantação de estradas de ferro, enquanto verdadeira rede viária, ficou na dependência da resolução do problema técnico da propulsão, ou seja, do desenvolvimento de uma locomotiva com eficiência suficiente para arrastar cargas maiores do que seu próprio peso e a velocidades crescentes: donde a caldeira tubular, em 1829, a dupla expansão, em 1876, e o superaquecimento do vapor d'água, em 1898. A expansão das vias férreas foi impressionante, conta Hobsbaum (1971). Em 1830, havia, na Inglaterra, em torno de umas duzentas milhas de trilhos; em 1840, passava das 4.500; e em 1850, das 23.500 .

O marcante em todo este progresso técnico é a forma de sua conquista. Regidas essencialmente por necessidades e problemas práticos, as soluções derivaram de esforços individualizados de engenheiros e contra-mestres que, em um típico método de ensaios e erros, aperfeiçoaram, inventaram e inovaram. Saltos maiores serão possíveis somente a partir de um raciocínio mais 
abstrato, promotor de um casamento relativamente estável entre ciência e tecnologia que vai não só implementar o transporte material, mas, sobretudo, inventar e revolucionar a transmissão de idéias através de seus signos. Assim se dá com o motor a explosão interna, que começa por resolver, mais confortavelmente, o problema da locomoção individual através de rodovias; assim ocorre com uma nova fonte de energia, a elétrica, que, alterando profundamente os processos produtivos, inicia um ciclo de consumo individual marcado pelo conforto racional na realização das atividades cotidianas e pela instauração de novos tipos de prazer (rádio, cinema e, depois, televisão). Por ela, tornam-se possíveis as telecomunicações, essenciais à administração pública, aos negócios e, por que não?, os prazerosos contatos interpessoais. O aeroplano, instrumento de guerra, vem a ser um meio indispensável de transporte de pessoas e mercadorias, concretização de propósitos que vão muito além do velho sonho humano de, como os pássaros, encontrar a máxima liberdade na infinitude dos céus.

O século XX inaugura-se sob a primazia da ciência, impulsionando a crença de que o homem tudo pode; superar não só a natureza tal qual ela se lhe oferece, mas, inclusive, a si próprio, em conquistas cada vez mais significativas. Dominando o grande, põe-se este ser 'cientificado' a controlar o pequeno, para o bem e para o mal. Nenhum modo de fazer empírico alcançaria uma tal potencialização da matéria como se vê na mais recente fonte energética 'fabricada', como aquela retirada dos átomos. Para o bem e para o mal, já se disse. Avanços que deveriam resultar, única e exclusivamente, em benefícios para toda a humanidade, instrumentam ações destrutivas resultantes de conflitos não propriamente criados pela ciência e pela tecnologia. Por aí, são elas, ciência e tecnologia, até mesmo condenadas, mitificadas que são como novos deuses discriminadores, excludentes dos muitos que querem entrar no paraíso.

Isabelle Stengers (1990) é, talvez, um bom exemplo de indignação do que ela qualifica como "relação privilegiada entre racionalidade científica e poder":

"Existe um belo filme, Aguirre, que conta uma das dimensões da utopia pela qual trabalho. Aguirre é um conquistador que, sobre uma jangada, desce, com seus soldados encouraçados e suas mulheres com vestidos caseiros, um rio aprisionado pelas muralhas verdes da selva. Ele assina documentos pelos quais toma posse de tudo que vê, de tudo aquilo que não vê. Todavia, Aguirre se torna louco. Ele jamais poderá encontrar, terrorizar e submeter os habitantes das margens, pois eles se escondem e deixam passar a estranha coisa. Ele não poderá, jamais, fazer diferença. Somente escarnecem sua passagem os macacos que, no fim do 
filme, invadem a jangada onde os espanhóis se entremataram. Aguirre não estava muito interessado em conquistar. Nada aconteceu."

Por isso, continua (idem, p. 206):

"eu sonho com uma ciência que, como no século XVIII, visava não um público pronto a se deixar impressionar, a se espantar, a se escandalizar ou a se submeter, mas com aquela dos amadores capazes de discutir, de apreciar e, em último caso, de rir dos 'golpes' que tentam os cientistas, da mesma maneira que, ainda hoje e se não conhecem o solfejo, são capazes de fazer uma diferença entre esta ou aquela interpretação musical. Não um público em pânico perguntando 'é verdade?', mas um público que exigiria um interesse pelo debate, que leria, não as vulgarizações, mas 'traidores' contando os interesses, os riscos, as apostas, tomando os riscos, também entre eles, promovendo controvérsias em direção a horizontes inatingiveis. Em resumo, complicando os jogos das ciências e dos poderes, dando densidade à rede, atualmente rarefeita, dos interesses que 'contam'."

Uma ciência e um poder essencialmente 'bons', dir-se-ia, 'politicamente corretos'.

\section{Razão e técnica}

A 'cientifização' da arte (técnica) não é mais que uma concretização avançada de um velho sonho: tornar racional o mundo através daquele que, apreendendo-o, o compreende e nele age como máxima causa eficiente. $\mathrm{O}$ homem, já se disse, difere da mais laboriosa abelha e de sua obra perfeita, pelo fato de antever o produto de seu trabalho. Antes de estar no mundo, a obra se apresenta (quase que por inteiro) na cabeça que comanda o refinado instrumento que é a mão. É o caráter teleológico do trabalho humano que sustenta o engenho e a arte, a criação que transforma o mundo modificando os homens. A questão, assim, é clara: o que vai pela cabeça dos homens? Em outras palavras, que racionalidade 'guia' o pensamento e as ações dele decorrentes?

Platão recusou a educação tradicional porque baseada, essencialmente, nos ensinamentos dos poetas e na confusa religiosidade por eles transmitida. Queria transitar não por noções ambíguas, mas por idéias precisas como as desenvolvidas pelos matemáticos, guiadas pela lógica que encadeava com rigor o antecedente e o conseqüente. Projeto que, sabe-se bem, buscando libertar os homens de interesses e paixões que mais não fazem que alimentar a violência e a injustiça, dar-lhes-ia a sabedoria apaziguadora de suas existências, a possibilidade de uma vida justa, pois que 
assentada na ordem, na eficácia e na razão. Modernidade que, opondo-se a antigas formas de expressão (lendas, mitos, poesia, política, relatos históricos), rejeitava uma outra proposição: a então nascente democracia e as necessidades dela decorrentes. Para que o povo possa se governar, é preciso que ele saiba falar. Não importa sobre o que e de que modo, desde que o faça bem. A retórica do sofista não é mais do que a expressão do interesse imediato, carecendo de rigor argumentativo, pensa nosso filósofo. Ensinamentos que se desdobram em formulações rígidas, como se vê na lógica formal aristotélica que, pelo silogismo, instaura o primado da não contradição. Será preciso esperar até o século XIX para que, com Hegel, a humanidade possa pensar a contradição sob um novo conceito de dialética. Mas isso é outra história...

O que merece ser ressaltado aqui é a mudança de ótica na visão das coisas. A exigência de uma lógica para a compreensão e regência do mundo significa a rejeição do mito, da crença e da opinião (doxa) interessada. Como vemos em Châtelet (1979, p. 14):

"Nesta época, gêneros culturais mudam de sentido e de estilo: a tragédia, fundamentalmente religiosa, transforma-se em cerimônia cívica; a comédia passa do jogo bufo à crítica política; outros se reforçam, como a história e geografia: as descrições lendárias e genealogias míticas são trocadas por paisagens e costumes precisamente descritos e analisados, sendo os eventos escrupulosamente relatados; outros (gêneros) nascem, como a medicina que, dali em diante, passa a procurar muito mais as causas das doenças que as fontes ambíguas da divinização ...."

Por isso, contra o mito do principal deus da medicina, Apolo, a arte médica 'racional' grega levantou a poderosa idéia de physis. Já se viu, a natureza não é mais que um florescimento dos elementos primordiais que, através das formas (causa formal), alcança suas finalidades. Água, terra, ar e fogo possuem qualidades; fria e úmida para a primeira; fria e seca, a terra; o ar úmido $e$ quente; e o fogo, quente e seco. A estes elementos correspondem, também, as quatro estações e, por desdobramento, os humores corporais: úmidos e quentes são a primavera e o sangue; ao fogo correspondem o verão e a bile amarela; tal como a terra, o outono e a bile negra são frios e secos, enquanto o inverno e a fleuma são frios e úmidos como a água. Encontrando-se todos estes elementos em harmonia, a saúde impera, para bem-estar e prazer dos indivíduos. O seu desequilíbrio caracteriza a doença, situação também ligada às estações anuais. Ora, se esta racional concepção do processo saúde-doença é verdadeira, uma conseqüência lógica se impõe, relativamente aos procedimentos terapêuticos. Se, "no tempo dos deuses" as pessoas se curavam e se não são os deuses 
que curam, "alguma coisa" deve fazê-lo. Vis medicatrix naturae (a cura pela natureza) é a explicação decorrente. Em conseqüência, e por coerência, a intervenção médica é, fundamentalmente, o acompanhamento do curso natural da doença. Daí o caráter maior do tratamento médico hipocrático: expectante e pedagógico. Ajudar, ou pelo menos não prejudicar, tornou-se seu princípio básico. Todavia, nada fazer não coaduna bem com a atitude do 'artista' que justamente assim se define por se querer capacitado a um específico fazer. Donde um comportamento também ativo do médico. De acordo com Novaes (1989, p. 32):

“A concepção hipocrática da natureza humana e.dos processos patológicos comporta uma dupla postura terapêutica. De um lado, o predomínio de um dos humores determinante do quadro mórbido requer uma intervenção, que contrarie esta dominação. Ressalte-se aqui a existência de uma explicação etiológica para o desequilíbrio dos humores, tais como as variações sazonais, a alimentação inadequada, o modo de vida irregular, "constituições" clímato-geográficas etc. Assim, se o quente é a causa mais próxima, recomenda-se o frio. Contra o seco, o úmido; e na pletora, evacuações. Segundo Guerra, a farmacopéia hipocrática compunha-se de mais de trezentos remédios, a maioria de origem vegetal e com propriedades purgativas, eméticas, diuréticas, diaforéticas, emolientes etc. O sentido básico era o de evacuar os humores excessivos, através das fezes, vômitos, urina e suores, configurando uma catarse ou limpeza corporal. O heléboro negro era um purgante universal e, o branco, um emético habitual."

Vê-se bem que, no caso da medicina, a técnica não se constrói, exatamente, no plano das tentativas e erros. Aqui, uma "teoria" antecede as ações, uma relação (de causa e efeito) embasa a compreensão, uma explicação orienta a prática. É certo que nenhuma "avaliação" sistemática se colocava como necessária a estes procedimentos, mesmo porque o sucesso da intervenção era debitado ou creditado muito mais ao artista do que, propriamente, à arte de curar. Mas, se considerarmos que a medicina hipocrática domina a cena da civilização ocidental desde o seu nascimento até o século XIX da nossa era, sem dúvida, alguma eficácia pode lhe ser atribuída. Todavia, dado que a prática é, também, 'corretora' do pensamento, modificadora da 'teoria', inovações foram sendo introduzidas tanto no modo de pensar como no de fazer. Assim, e se de um lado a cultura latina pouco ou nada com ela contribuiu, o mesmo não se pode dizer da civilização árabe. Responsáveis pela guarda e difusão dos tesouros clássicos, os árabes acrescentaram novos elementos à medicina, até mesmo enfatizando aspectos que, originalmente, não configuravam seus traços maiores. 
Galeno (129-200) aporta, pelo menos, duas novidades à arte médica. Segundo Guerra (1992), foi ele quem iniciou o conhecimento sistemático e total da anatomia humana aplicada ao diagnóstico e tratamento das enfermidades humanas, dissecando animais domésticos e macacos, estes últimos não por acaso. Em última análise, sua preocupação, para além das formas, era com a função de cada parte que compõe o todo orgânico e, por isso, em seus escritos,

"a ordem de exposição reflete a concepção teleológica da (sua) anatomia, que interpreta a estrutura anatômica de cada uma das partes do corpo em função da forma mais adequada para realizar a atividade própria do animal ou do ser humano. A mão e o braço seriam expressão dos órgãos da razão com os quais o homem constrói os instrumentos para relacionar-se com o meio ambiente e com os outros homens" (idem, p. 172).

Postura com a qual, entre outros aspectos, inicia-se o longo trajeto que mudará de negativo para positivo o valor do trabalho manual. Todavia, ao lado deste aspecto 'sócio-econômico', estáse diante de um primeiro passo relativo ao conhecimento que diz respeito à internalidade das estruturas corpóreas e a um pensamento quase fisiológico que repercute através da segunda 'novidade' aludida anteriormente. A terapêutica galênica guiavase pelo diagnóstico fisiopatológico, firmado pela identificação do 'humor' afetado, fundamentalmente, pelo ambiente e pelos alimentos. Fácil é compreender que, se A é a causa da doença, o anti-A o será da cura. Assim, enfatizando o lado menor da terapêutica hipocrática, Galeno instaura o máximo princípio contraria contrariis curantur (a cura pelos contrários). É certo que serão seus seguidores os que levarão quase ao paroxismo esta máxima e que resultará, muito mais tarde, em reações radicais como foi, por exemplo, a homeopatia.

Todavia, alguns outros passos ainda deveriam ser dados na construção de um novo (e moderno) objeto da medicina. Dois mil anos de história começam a ser revistos, a partir de controvérsias de ordem terapêutica. Como se sabe, para se recuperar o equilíbrio dos humores indicava a lógica que se eliminasse o excesso, sendo a sangria o meio mais expandido e universalizado. Duas correntes se opunham: os que sustentavam que a sangria deveria ser feita do mesmo lado da lesão e aqueles que, ao contrário, propunham a contralateralidade. Uma controvérsia que, por mais absurda que hoje nos possa parecer, levantava um problema cuja solução representou, em definitivo, um avanço no conhecimento médico, dado que, mais do que as funções das partes (como se vê em Galeno), pergunta-se pela estrutura do todo. Em 1543, Vesálio publica De Humani Corporis 
Fabrica, uma verdadeira "ruptura epistemológica", no entender de Cid (1985). É que, aqui, a estrutura antecede a função ou, melhor dizendo, as funções só podem ser compreendidas a partir do arcabouço material que lhes dá sustentação. De certo modo, a função orgânica vem a ser a própria estrutura em movimento.

A anatomia vesaliana, colocando novas bases para o entendimento do corpo humano, vai permitir que, ao final do século XVIII, o nível macroestrutural deste conhecimento estivesse praticamente completado. É por ela e a partir dela que novas indagações vão surgir para o pensamento médico, inclusive pelo questionamento da teoria humoral, enquanto explicação da saúde e da doença. Como expõe Novaes (1989, p. 49):

"E Sedibus et Causis Morborum per Anatomem Indagatis, publicado em 1761, Morgagni expõe quinhentos casos nos quais constam a história clínica de cada um deles, os antecedentes patológicos e suas conseqüências, as circunstâncias do óbito e, por fim, os estudos necroscópicos. A demonstração que se procura é a da relação entre sintomas e lesões, de tal forma que, se as últimas resultam dos primeiros, passariam eles a ser os anunciadores antecipados de um fim previsível. Por isso, aponta $\mathrm{Cid}$, a exposição das doenças em cada um dos livros que compõem - De Sedibus (cabeça, tórax, abdômen e "enfermidades cirúrgicas") tem um conteúdo classificatório baseado na lesão patológica. Conhecer antes de ver é o objetivo de um axioma morgagniano, segundo o qual a lesão é escrava do sintoma."

É certo que a vertente aberta pela 'interiorização do corpo' sofrerá a 'concorrência' da medicina das espécies, como bem analisou Foucault (1988). Tratava-se esta, no fundamental, de uma ênfase metodológica, da busca de um rigor classificatório, tal como vinha sendo desenvolvido, principalmente, pela botânica. Será preciso que a ordem de Bichat (abrir os cadáveres) seja atendida para que a doença seja concebida como processo intracorpóreo e localizado, sustentando a separação dos sinais e sintomas e 'objetivando' a atividade clínica. Um novo modo de apreender a doença vai se constituindo, pois que uma nova compreensão da mesma vai se instaurando. A doença não mais será um desequilíbrio dos humores e muito menos "espécies mórbidas" ou miasmas emanados de específicas "constituições geográficas". Materializada no corpo, a lesão passa a ter visibilidade, localização e, principalmente, um começo. Correlacionando morte e vida, a clínica, agora antevisão, introduz um novo conceito que revolucionará a prática dos médicos: a evolução. Claro que o prognóstico, desde sempre, configurou-se como elemento fundamental na arte de curar, principalmente como indicador da qualidade não da arte, mas daquele que a exercitava. Todavia, 
assentava-se na mera observação do "curso natural da doença", que, uma vez reconhecido, tornava-se padrão de uma predição. Aqui, com a clínica, evolução quer significar eventos necessariamente encadeados, expressos na idéia de processo. Em outros termos, é possível prever um determinado fim não simplesmente pela sua naturalidade, mas pela explicação possível de cada uma das etapas que constituem o conjunto. Por isso, a materialidade da lesão, como queria Bichat, não pode ser a explicação acabada, pois, como e por que começam elas? E mais, por que não são encontradas em situações que passaram a ser reconhecidamente patológicas, como as doenças mentais? E ainda, como se passam as coisas se nenhuma doença é identificada?

\section{Medicina científica}

Claude Bernard (1984, p. 25) é categórico:

"para abraçar o problema médico na sua totalidade, a medicina experimental deve compreender três partes fundamentais: a fisiologia, a patologia e a terapêutica. O conhecimento das causas dos fenômenos da vida no estado normal, quer dizer, a fisiologia, nos ensinará a manter as condições normais da vida e a conservar a saúde. O conhecimento das doenças e das causas que as determinam, quer dizer, a patologia, nos conduzirá, de um lado, a prevenir o desenvolvimento destas condições mórbidas e, de outro, a combater seus efeitos através de agentes medicamentosos, quer dizer, a curar as doenças."

Conviç̧ão derivada de uma ruptura teórica que, hoje, pode nos parecer singela e simples. Antes de Claude Bernard, afirma Dagognet no prefácio à Introduction, o mundo dos vivos se dividia em dois reinos, complementares e hostis entre si: o reino vegetal, fabricante de açúcar, e o reino animal, que dele retira a energia necessária ao seu funcionamento. Em outros termos, só os vegetais constituem-se em produtores e reservatórios energéticos. Se assim é, como explicar o diabetes, que tem na glicosúria seu sinal maior? Estudando cães, alimentados exclusivamente com carne, Claude Bernard identifica a presença de açúcar no sangue destes animais, derrubando a teoria, então vigente, da exclusiva fonte vegetal.

Algumas conseqüências podem daí derivar. Em primeiro lugar, um novo modo de fazer ciência. A quantificação vem a ser o parâmetro fundamental no desvendamento dos fenômenos vitais, postos agora como novo objeto do conhecimento. Naturalmente, procedimento tornado possível por inovações técnicas e científicas, como a própria dosagem dos elementos químicos. Bachelard dirá, mais tarde, que os novos instrumentos são, também, 
responsáveis pela criação de novos objetos científicos. Em segundo, é medindo que Claude Bernard identifica uma relativa constância do elemento em estudo (o açúcar) mesmo na ausência de seu aporte. A descoberta da glicogênese será a base para a proposição de regulação e de meio interior que conferem uma relativa independência do ser vivo, consideradas as alteraçôes do meio cósmico. Finalmente, uma terceira (entre inúmeras outras) conseqüência exprime-se em um novo conceito de saúde e de doença:

"O organismo não é mais do que uma máquina viva construída de tal maneira que há, de um lado, uma comunicação livre do meio externo com o meio interior orgânico e, de outra parte, funções protetoras dos elementos orgânicos que colocam em reserva os materiais da vida e mantêm a umidade, o calor e outras condições indispensáveis à atividade vital. A doença e a morte não são mais que deslocamento ou uma perturbação deste mecanismo que regula o contato de excitantes vitais com os elementos orgânicos" (idem, p. 119).

O que Claude Bernard propõe é uma verdadeira inovação. A teoria do desequilíbrio, como explicação da doença, admitia, em última análise, uma diferença qualitativa em relação ao "estado de saúde", pois, como se sabe, o excesso de algum dos humores vinculava-se, por exemplo, a particularidades climáticas e/ou geográficas. Assim também se passou com a explicação 'botanizada' da medicina das espécies. Aqui, a quantidade impera, e saúde e doença não são mais do que variações sobre um mesmo tema. Canguilhem, de forma magistral, aponta a solução bernardiana para a dificuldade colocada pela nova metodologia. Identificar o normal com saúde e o anormal com patológico significa, por um lado, atribuir a um conceito de valor características próprias de uma regularidade estatisticamente apreendida. De outra parte, conceber a doença como anormalidade não é mais do que imaginar, no ser vivo que sofre, a ausência de normas. Assim, e a rigor, a saúde seria uma condição de absoluta estabilidade, enquanto a doença, uma indefinição plena dada pela ausência de parâmetros. Claude Bernard vale-se de uma tradição empirista já presente no pensamento médico para solucionar o problema qualidade/quantidade. Subordinando um conceito de valor (norma) a uma noção meramente descritiva (anomalia retrata o que é desigual, diferente), é possível se estabelecer uma continuidade entre saúde e doença, diferenciadas tão-somente por um ponto de inflexão definidor do desvio da 'constante fisiológica'.

Com Claude Bernard, estabelece-se uma sólida base para o desenvolvimento da medicina moderna. A experimentação define- 
se pela interferência programada e controlada sobre os processos vitais, tomados na particularidade isolada de cada um deles. Caracteristicamente analítica, a medicina experimental visa a construção paulatina de uma síntese, delimitando, todavia, esferas de competências privilegiadas. A primeira é a do normal, pela qual se pode conhecer o patológico, reconhecê-lo em situações individuais, tudo como fundamento da intervenção terapêutica.

Na verdade, o que a fisiologia bernardiana busca é uma saída para a profunda crise vivida pela medicina, em uma Europa Ocidental transformada em palco de aceleradas revoluções econômico-políticas e técnico-científicas. Questionada e mesmo ridicularizada por seus resultados terapêuticos, a arte médica assiste, cada vez mais, a uma dissociação entre a técnica e seus fundamentos. Em que pese algumas inovações ocorridas na segunda metade do século XIX, como a anestesia e a assepsia, é somente com Pasteur que ocorrerá uma revolução propriamente terapêutica. Encontra-se aqui uma causa material, visível e individualizante das doenças, fundamentando procedimentos consagrados somente pelos seus efeitos, como foi o caso da vacina de Jenner. A arte médica inicia então sua 'época de glória', dado que se torna possível um reencontro quase acabado entre a teoria e a prática, marcado, todavia, por uma nova qualidade: a eficácia, ou seja, a obtenção de um efeito desejado. Sem dúvida, a nova técnica proporcionou ações de amplitude maior do que aquelas que até então se aplicavam ao nível individual. O saneamento não é mais uma simples rejeição de deletérias condições de vida, humanisticamente intoleráveis. Cientificamente fundamentado, constrói-se como um conjunto de ações de proteção coletiva, ainda que para atender interesses particularizados, como se viu na grande obra de Oswaldo Cruz.

O triunfo da técnica médica se faz sentir, em mais um passo, quando a proteção aos indivíduos vem a não mais depender de uma reação induzida do organismo, mas de uma ação que consagra a velha máxima do contraria contrariis curantur. A antibioticoterapia surge com ares da também velha idéia de panacéia, solução para a quase totalidade dos problemas que afligem o ser humano. Sabemos que as coisas não se passam exatamente como imaginadas, inclusive porque à pretendida supremacia técnico-científica são atribuídos resultados perversos, agrupados sob o termo iatrogenia. Há aqui, sem dúvida, uma trágica conjunção de interesses e ignorâncias, inaceitável quando os primeiros dominam a cena, às vezes sem qualquer escrúpulo. Quanto ao não saber, novas barreiras vão sendo mais precisamente identificadas no próprio terreno da biologia humana. Nesse sentido, o que se poderia identificar como convivência de duas teorias explicativas da doença começa a passar por um certo processo de convergência. Se, de um lado, a fisio- 
patologia assenta-se no paradigma do 'contínuo interno', de outro, o pasteurismo consagrou a idéia de 'agressão'. A momentânea oposição destas concepções passa por uma possibilidade de 'conciliação' com o avanço da compreensão de mecanismos mais íntimos da estrutura, organização e funcionamento dos organismos. A genética, redescoberta, vai abrindo um novo mundo para a atividade médica. Mundo que, todavia, é o do entendimento, ainda algo distante de uma intervenção positiva, pois que comporta somente técnicas preventivas do tipo aconselhamento genético, de eficácia duvidosa.

Novos saltos serão necessários e, mais uma vez, não exclusivamente no campo médico, com repercussões que dizem respeito mais de perto a interesses outros que aqueles propriamente de saúde. Se se considera que em apenas treze anos, da preocupação de estudar a estrutura físico-química dos genes, passou-se, com Watson e Crick (1953), à decifração da estrutura do DNA, verifica-se um ritmo inusitado na produção de conhecimentos. O desenvolvimento da química, da física ("ciência das ciências") e a contínua invenção (e inovação) de instrumental técnico-científico constituem-se em importantes bases para o estabelecimento de um novo paradigma tecnológico: a biotecnologia. Por aí, decifra-se o código genético, Jacob e Monod (1966) entendem que o processo de produção de proteínas requer a presença do RNA mensageiro e, em 1970, descobrem-se enzimas de restrição, capazes de 'cortar' a molécula do DNA sempre nos mesmos e precisos lugares. Pode-se bem alcançar a potencialidade de tal instrumento na decifração dos chamados erros genéticos, passíveis agora não só de um reconhecimento descritivo, mas de uma compreensão de seu 'intimo' mecanismo. Mais longe se vai quando, pela primeira vez, logra-se uma transferência de gene (1973, por Boyer e Cohen) seguido, dois anos depois, pela fabricação do primeiro hibridoma, base essencial para a produção dos anticorpos monoclonais. Percebe-se bem a potencialidade destes avanços técnicos, calcados em um desenvolvimento científico sem precedentes. Donde não causa hoje nenhum estranhamento que uma proteína tenha sido artificialmente produzida e que, em 1981, o engenho técnicocientífico tenha conseguido tornar disponível o primeiro teste diagnóstico com anticorpos monoclonais, vale dizer, um modo de fazer absolutamente eficaz, efetivo e, no limite, 'totalmente' eficiente. Descoberto o caminho, os desdobramentos são, $a$ posteriori, plenamente previsíveis: vacinas são artificialmente produzidas e, em 1982, um primeiro produto terapêutico surge do labor da engenharia genética. A insulina para uso humano passa a ser produzida por... bactérias. Técnicas 'ousadas' (altamente promissoras no campo da alimentação humana, por 
exemplo) assumem ares de um novo deus criador, ao produzirem, por clonagem, indivíduos idênticos até então possiveis somente no campo da ficção.

A vida vai, cada vez mais, desvendando-se aos olhos ampliados da ciência e tornando-se objeto de intervenções incisivas e radicais. As técnicas de transplantes levam a pensamentos, para alguns, inumanos, pois que possibilitam analogias mecânicas como aquelas relativas às "peças de reposição". Acessível, a intimidade do ser pode, através de "sondas genéticas", revelar erros do metabolismo produtores de sofrimento e, por vezes, incompativeis com certas exigências sociais dominantes, excludentes de conformações biológicas tidas como deficientes e deficitárias. De outra parte, a reprodução humana medicamente assistida pode permitir, ao contrário, responder a eventuais necessidades de outras ordens, na definição sexual de nossos futuros semelhantes, por exemplo.

Compreende-se bem a gama de possíveis conseqüências deste domínio técnico-científico sobre a natureza, notadamente sobre aquela humana. Em uma decisão histórica, a Corte Suprema dos Estados Unidos da América reconheceu um ser vivo como produto artificial, concedendo patente industrial a um gênero de pseudomonas que, modificado pela engenharia genética, tornouse capaz de degradar hidrocarbonetos. Órgãos humanos, 'peças de reposição', muito facilmente se transformam em 'simples' mercadoria à disposição de um mercado que, suspeita-se, tornase florescente. E que problemas colocam a possibilidade de diagnósticos cada vez mais precoces de doenças genéticas!... Deve uma gravidez ser interrompida em decorrência do fato de que um futuro ser padecerá por causa da anemia falciforme? Selecionando os futuros indivíduos, não estaria a tecno-ciência dando alento a uma das formas de exclusão, expressa por um certo pensamento eugênico?

\section{Construindo o mal?}

Questões ético-morais, sem dúvida, mas não exatamente novas. Não valeu-se, o honrado Sócrates, da tecnologia disponível para cumprir os desígnios a ele impingidos por seus democratas concidadãos? Maquiavel, relembre-se, elabora a técnica do "bem governar" (distinguindo o político da esfera da moral), propiciando interpretações que sancionam a máxima segundo a qual "os fins justificam os meios". Quantos aplausos não se produziram diante dos horrores de Hiroshima, possíveis pelo domínio técnicocientífico do pequeno mundo atômico, fonte de liberação energética até então jamais pensada?

Questões pertinentes e aflitivas mas que, como toda questão, não são moedas de um só lado. Ética e moral, bem se vê, são 
valores que, resgatando princípios, expressam-se em novos conteúdos e formas, mais ou menos consoantes com os tempos que lhes são dados visitar. Por aí, talvez se possa alcançar as razões de um François Jacob (1981, pp. 11-2), por exemplo, em uma assertiva inúmeras vezes questionada e por muitos, certamente, rejeitada:

"Desde alguns anos, faz-se muitos reproches aos cientistas. Acusase-os de serem sem coração e sem consciência, de não se interessarem pelo resto da humanidade; e de serem, até mesmo, indivíduos perigosos que não hesitam em descobrir meios de destruição e de coerção terríveis, e deles se servirem. Isso os deixam honrados. É notável o número de imbecis e malfeitores que se encontra em todos os níveis de uma população, sejam cientistas, agentes de seguro, camponeses, padres ou políticos. E, apesar do dr. Frankenstein e do dr. Folamour, as catástrofes da história decorrem menos dos cientistas do que de padres e políticos. Porque não é somente o interesse que faz os homens se matarem. É também o dogmatismo. Nada é tão perigoso como a certeza de se ter razão. Nada causa tanta destruição como a obsessão de uma verdade considerada como absoluta. Todos os crimes da história são conseqüências de algum fanatismo. Todos os massacres foram feitos pela virtude, em nome da verdadeira religião, do nacionalismo legítimo, da política idônea, da ideologia justa; em resumo, em nome do combate contra a verdade do outro, do combate contra Satã. Esta frieza e esta objetividade que se reprova, freqüentemente, nos cientistas, talvez fossem elas mais convenientes ao ardor e à subjetividade, no trato de certos negócios humanos. Porque não são as idéias da ciência que engendram as paixões. São as paixões que se utilizam da ciência para sustentar sua causa. A ciência não conduz ao racismo e ao ódio. É o ódio que faz apelo à ciência para justificar seu racismo. Pode-se reprovar o ardor com que, às vezes, certos cientistas defendem suas idéias. Mas nenhum genocídio foi, ainda, perpetrado para fazer triunfar uma teoria científica. Ao final deste século $\mathrm{XX}$, deveria ser claro para todos que nenhum sistema explicará o mundo em todos seus aspectos e detalhes. Ter contribuído para quebrar a idéia de uma verdade intangível e eterna não é, talvez, o menor dos títulos de glória da caminhada científica."

Esta longa citação denota, talvez, o envolvimento apaixonado do cientista com a sua atividade. Sem isolá-las, mas distinguindoas, o pensador aponta para as especificidades de práticas e objetos que não podem ser imediata e mecanicamente confundidos. Ciência e ideologia, técnica e política, certamente se tocam e se mesclam sem, todavia, perderem os traços que lhes caracterizam 
ainda que, a posteriori, facilmente se identifique a preponderante influência de uma sobre a outra. A ciência pode vir a se revelar como "pura ideologia". Quanto à política, trata-se, certamente, de um tipo específico de tecnologia, qual seja, a clos modos sociais de fazer as coisas do mundo. Fórmulas encontram-se, com alguma abundância, em pensadores que, refletindo sobre seus diferentes tempos, não as viram realizar-se de acordo com a ideação produzida. Uma delas, talvez pelo seu grau de generalidade, parece ainda guardar uma substancialidade (positiva), inclusive por expressar possibilidades totalmente abertas à infinita aventura humana: "os homens fazem a história nas condições que lhes são dadas fazê-la". Assim a vida, assim a ciência, a produção, a técnica e a arte.

Assim a vida e seus modos de andar (allure), diria Canguilhem. Nem tudo está estabelecido a priori, a não ser a necessidade de normas. Biológicas, são elas iniciais e fundantes, existentes e operantes na anterioridade mesmo de sua percepção e compreensão. Normas que organizam o ser, fornecendo-lhe condições para mudanças que serão qualificadas por um ato de criação, propriamente humano, é o cultural. Este é o senticlo da norma e, ao sucesso, não se pode atribuir senão um valor positivo que quer significar o novo, a criação, a transgressão. Em outros termos, as mudanças operadas pelo ser serão bem-sucedidas, positivamente valoradas, se ele ultrapassa os limites 'normais' que the são inicialmente impostos. Donde o neologismo canguilhemiano: normatividade é a capacidade do ser de, criando normas pelo rompimento com aquelas existentes, pôr a novidade no mundo sem descaracterizar o que lhe é essencial. Por aí, uma definição não tautológica de doença e saúde pode ser ensaiada: a primeira se caracteriza pelo domínio de normas biológicas inferiores, potencialmente catastróficas para o ser. Se sadio, ele terá a capacidade de, rompendo com tais regras, impor novas e superiores normas que the possibilitarão um passo a mais rumo a um ponto não passível de determinação. Em outros termos, ser sadio é poder adoecer e se curar.

Definição parcial, certamente. Um vegetal, regido por normas inferiores e catastróficas reage, mas não julga e não age. $O$ valor, já se disse, é criação cultural porque humana. Nesse sentido, mais importa o juízo e a ação do que o jogo natural das normatividades. Assim, e dado que saúde é um julgamento de valor, talvez a definição se completasse nos termos que se seguem: saúde é o processo biológico regido por normas vitais superiores, sobredeterminado por valores histórica e periodicamente dominantes. Se assim é, a questão que se coloca é a que se segue: que valores são hoje dominantes, pelo menos no que diz respeito às sociedades ocidentais? Certamente o de liberdade 
que, democraticamente construída, configuraria uma igualdade reforçadora de uma pretensa fraternidade. Donde as noções de direito e cidadania, mais precisamente, direito à cidadania. Bem se vê que o direito, como princípio, pressupõe o seu contrário, o não direito, uma existência ainda a ser conquistada. É que, na produção capitalista, outros valores se impõem e, dentre eles (talvez o principal), o de eficiência. Nesse contexto, já se viu, destacam-se o conhecimento e a ação racional dele derivada. Ciência e tecnologia são não apenas elementos eficazes no domínio e modificação da natureza, mas altamente valorizados por uma sociedade que, cada vez mais, cultiva facilidades e confortos. Assim valorizada, a ciência tem sido colocada como referência máxima, inclusive nela se procurando soluções para problemas que dizem respeito muito mais às formas de organização social dos homens. Quanto à saúde e seu conceito, os valores dominantes não poderiam assentar-se senão no conhecimento do biológico que lhes dá fundamento. Em outras palavras, é o próprio conhecimento do biológico que embasa as noções de saúde e doença, orientando as técnicas de intervenção nos níveis individual e coletivo.

Daí decorre a questão da saúde, muito mais por uma colusão de valores do que por uma insuficiência dos conhecimentos. Fundando-se na racionalidade (científica), a explicação dos fenômenos e as soluções dela derivadas deparam-se com exigências centradas em valores socialmente tidos como fundamentais. Dito de outro modo, pode-se afirmar que, hoje, o conhecimento das doenças e seus tratamentos são 'negócios' fundamentalmente científicos e tecnológicos, mas com a missão exigida de resolver todos os problemas de todas as pessoas. $\mathrm{O}$ direito à cidadania (igualdade) é desejado como um valor dominante, universalizante, inclusive como orientador da atividade técnico-científica. Em outras palavras, ciência e tecnologia, além de terem finalidades utilitárias previamente definidas (o bem), devem responder positivamente a demandas mais amplas, como se delas decorressem os conflitos responsáveis pelas desigualdades e exclusões sociais. Que seus resultados são elementos cooperativos da manutenção de injustas situações, dúvidas não há. Mesmo porque são elas, ciência e técnica, produtos da história, da forma pela qual as sociedades se organizam. Todavia, são seus resultados que, também, têm proporcionado ações benéficas ao nível mais amplo, como se pode verificar nos exemplos da varíola e, mais recentemente, da poliomielite. O problema, mais uma vez, é o da distribuição de tais resultados e, aí, a solução não é meramente técnica ou científica, mas política, ou seja, ação de todos os cidadãos que assim se querem. Mas, e de novo, isso é outra história... 
NOVAES, R. L. 'Sobre a técnica'. História, Ciências, Satide - Manguinhos, III (1): 24-49 mar.-jun. 1996.

Partindo de concepções forjadas na Grécia clássica, afirma-se a idéia de 'técnica' como 'modo de fazer' portador de características relacionadas às formas de organização das sociedades onde emerge, compreendidos os saberes que cada época produz. Destacando alguns aspectos dos diversos momentos da história ocidental, apontam-se relações existentes entre técnica e ciência, entendida esta última como a busca da máxima racionalidade. Questionam-se certas posições que parecem atribuir à tecno-ciência um papel deletério, dado o conluio que haveria entre saber e poder na produção de desigualdades e injustiças sociais. No caso da medicina, sustenta-se que a ciência moderna tem fundamentado técnicas de intervenção cada vez mais eficazes, em benefício do homem e que a não resolução de todos os problemas da humanidade deriva muito mais do caráter político das desigualdades do que de um papel específico da ciência e da técnica na sua determinação.

PALAVRAS-CHAVE: técnica, ciência, desigualdades sociais, medicina.

\section{REFERÊNCIAS BIBLIOGRÁFICAS}

Aristóteles 1991

Bernard, C. 1984

Châtelet, F. (org.) 1979

Cid, F. 1985

Eco, Umberto

Foucault, $\mathrm{M}$. 1988

Guerra, F. 1982

Hobsbaum, E. 1971

Jacob, F. 1981

Jacomy, B. 1990

Koyré, A. 1973

Maquiavel, N. 1973

Marx, K. 1973

Novaes, R. L. 1989

Stengers, I. 1990
Sur la nature (Physique II). Paris, Librairie Philosophique J. Vrin.

Introduction à l'étude de la médecine expérimental. Paris, Flamarion.

La Philosophie. De Platon à St. Thomas. De Galilée à J.J. Rouısseau. Bélgica, Marabout.

Breve história de las ciencias médicas. Barcelona, Expaxs.

O nome da rosa. Rio de Janeiro, Record.

Naissance de la clinique. Paris, Presses Universitaires de France.

Historia de la medicina. Madri, Ediciones Norma.

Las revolucionesburguesas. Madri, Ediciones Guadarrama

Le jeu des possibles. Paris, Librairie Arthème Fayard.

Une bistoire des techniques. Paris, Éditions du Seuil.

Éudes d'bistoire de la pensée scientifique. Paris, Éditions Gallimard.

O Principe. Escritos Políticos. São Paulo, Editora Abril. Coleção Os Pensadores.

El capital. Buenos Aires, Editorial Cartago.

O tempo e a ordem, sobre a homeopatia. São Paulo, Cortez/Abrasco.

'La raison dans les sciences: fiction et mobilizacion'. Em Roger-Pol Droit (org.), Science et philosophie, pour quoi faire? Paris, Le Monde Édition. 